Annales Missiologici Posnanienses t. 24 (2019), s. 75-83

doi: $10.14746 / \mathrm{amp} .2019 .24 .5$

ORCID: 0000-0002-3772-3427

ZOFIA KACZMAREK

Uniwersytet im. Adama Mickiewicza w Poznaniu

Wydział Teologiczny

\title{
Misyjny wymiar duchowości Świętej Teresy od Dzieciątka Jezus
}

Patronką misji ogłosił świętą Teresę od Dzieciątka Jezus 14 grudnia 1927 r. papież Pius XI, a dokonał tego aktu pod wpływem oddolnej inicjatywy kręgów misyjnych. Patronat ten także dzisiaj wydaje się pozostawać w konflikcie z faktem, że Święta Teresa nigdy nie udała się na misje, realizując swoje apostolskie posłannictwo w karmelitańskim klasztorze. Niniejszy artykuł przybliży kwestię misyjnego posłannictwa, jakiego podjęła się Święta Teresa z Lisieux, oraz zaprezentuje jego aktualność we współczesności poprzez odwołanie się do myśli Vaticanum II i do encykliki Redemptoris missio Jana Pawła II.

\section{„Misyjność” Świętej Teresy}

Na początku tej części refleksji warto pokrótce przybliżyć samą postać Świętej Teresy z Lisieux (właściwe: Maria Franciszka Teresa Martin), urodzonej 2 stycznia 1873 r. w Alençon, a zmarłej 30 września 1897 r. w Lisieux. Święta Teresa od Dzieciątka Jezus była ostatnim z dziewięciorga dzieci Ludwika i Marii Zelii Martin. W wieku sześciu lat po raz pierwszy przystąpiła do sakramentu pokuty, następnie udzielono jej - w opactwie benedyktynek w Lisieux (gdzie się uczyła) - w 1884 r. Pierwszej Komunii Świętej, a po upływie kilku tygodni sakramentu bierzmowania. Cechowała ją emocjonalna chwiejność i infantylność spowodowana wczesną utratą matki, nad którą to postawą zdołała zapanować dzięki nawróceniu mającemu miejsce w 1886 r. w święto Bożego Narodzenia. Za przykładem starszych sióstr, Pauliny i Marii, zdecydowała się wstąpić do Karmelu. Nieprzyjęta ze względu na wątłość i zbyt młody wiek (piętnaście lat), udawszy się z pielgrzymką do Rzymu, poprosiła 20 li- 
stopada 1887 r. papieża Leona XIII o umożliwienie jej wstąpienia do wspomnianego zakonu kontemplacyjnego. Uzyskawszy papieską zgodę, 9 kwietnia 1888 r. została karmelitanką w Lisieux, następnie 10 stycznia 1889 r. przyjęła habit, a w święto Narodzenia Matki Bożej - 8 września 1890 r. - złożyła śluby zakonne. Umarła, wycieńczona gruźlicą. Na dwa lata przed śmiercią, 9 czerwca 1895 r., oddała siebie Bogu w Akcie ofiarowania Miłości Miłosiernej. Zresztą we francuskich klasztorach karmelitańskich, za życia Świętej Teresy od Dzieciątka Jezus, powszechnym zwyczajem było poświęcanie się „na ofiarę całopalną Bożej sprawiedliwości dla wynagradzania za grzechy i dla zbawienia grzeszników" (Bernyś, 187). Święta Teresa od Dzieciątka Jezus nie stanowiła tutaj wyjątku.

Życie zakonne tej świętej charakteryzowało się wiernością i gorliwością w rozmaitych posługach, realizacją miłości jako wyznacznika i celu doskonalenia się, zagłębianiem się w tajemnicę Kościoła oraz, co najistotniejsze dla tematu, dojrzewaniem powołania apostolskiego i misyjnego. Święta Teresa pragnęła doprowadzić wszystkich do Jezusa Chrystusa. Wzrostowi jej ducha i zapału misyjnego sprzyjały też zewnętrzne okoliczności, do których można zaliczyć zainteresowanie się w drugiej połowie XIX w. ludami Azji i Afryki, nowe odkrycia geograficzne, ułatwioną komunikację i transport dzięki nowo powstałemu Kanałowi Sueskiemu tudzież ewolucję postaw mocarstw kolonialnych. Takie okoliczności przyczyniły się również do pojawienia się w Kościele nowych zgromadzeń misyjnych. W szczególności „misyjna wiosna” stała się zauważalna we Francji. O owej „wiośnie” w rodzimym kraju Świętej Teresy świadczyło chociażby to, że według statystyk „w 1900 roku na trzech misjonarzy ad gentes przypadało dwóch Francuzów" (Zieliński 234).

Duch misyjny obecny był w całej rodzinie Martin. Stanisław Zieliński pisze, że rodzice świętej „prenumerują pisma misyjne, a także rokrocznie przeznaczają pewną sumę pieniędzy na dzieła misyjne" (Zieliński 235). Ponadto rodzice Świętej Teresy pragnęli, żeby jedno z ich dzieci zostało misjonarzem. Również zakon karmelitański, do którego wstąpiła święta, w pewnym sensie cechował się „misyjnością”. Wyraziło się to np. w ufundowaniu w $1861 \mathrm{r}$. domu w Sajgonie, utworzeniu pod koniec XIX stulecia nowej fundacji karmelitańskiej w Hanoi, w personalnym i duchowym wspomaganiu misji przez karmelitanki oraz w duchowej współpracy (np. poprzez korespondencję) z misjonarzami.

Wstępując do Karmelu w Lisieux, Święta Teresa zamierzała partycypować w zbawianiu dusz i wspierać kapłanów - zwłaszcza misjonarzy - poprzez modlitwę, ascezę i ofiarę, realizując swoje misyjne powołanie na drodze miłości i pokuty. W jednym ze swych wierszy wskazała takie formy uczestnictwa w misyjnym dziele jak: ,modlitwę, miłość, umartwienie, pokutę, cierpienie, ofiarę i małe akty cnót" (Zieliński 240). Pragnienie bycia misjonarką pojawi- 
ło się w niej w momencie odkrycia, że jej powołaniem jest urzeczywistnianie chrześcijańskiej miłości do Boga i ludzi. Odkrycie to dokonało się pod wpływem Bożego natchnienia, przy lekturze Pierwszego Listu do Koryntian (1 Kor 12). Święta Teresa zrozumiała wtedy, że jej powołaniem jest miłość oraz że „miłość zawiera w sobie wszystkie powołania”, a więc także misyjne. W jej wyznaniu: „w Sercu Kościoła, mej Matki, będę Miłością” (Teresa od Dzieciątka Jezus 1957, 184) kryje się uzasadnienie jej eklezjalnego powołania, w którym mieści się powołanie ad gentes. Akt Ofiarowania się Miłości Miłosiernej okazał się w przypadku Świętej Teresy aktem o wielkiej wartości misyjnej. Następująco o misyjnej postawie Świętej Teresy pisze jej siostra Celina:

gdy Teresa miała 14 lat, po tym jak je Teresa nazywała 'swoim nawróceniem' życie zakonne przedstawiało się jej jako środek do zbawienia dusz. Nawet myślała zostać zakonnicą w zgromadzeniu misyjnym, lecz nadzieja zbawienia większej ilości dusz przez umartwienie i ofiarę z siebie spowodowała, że zamknęła się w Karmelu (Zieliński 236).

Święta Teresa pozostawała $\mathrm{w}$ duchowym kontakcie $\mathrm{z}$ dwoma misjonarzami. W Dziejach duszy zapisała: „Tymczasem Jezus nie tylko wyświadczył mi łaskę, której pragnęłam, ale połączył mnie więzami duchowymi z dwoma swymi apostołami, którzy stali się moimi braćmi [...]" (Teresa od Dzieciątka Jezus 2002, 297), pewna realizacji, poprzez duchowe wspieranie misjonarzy, charyzmatu zakonnej wspólnoty. W liście do jednego z nich stwierdziła: „Będę doprawdy szczęśliwa, współpracując z Ojcem dla zbawienia dusz, w tym celu przecież wstąpiłam do Karmelu, i nie mogąc być misjonarką czynną, chciałam być nią mocą miłości i pokuty, jak Święta Teresa, moja heroiczna Matka” (Teresa od Dzieciątka Jezus 1971, 667).

Dzięki owej duchowej więzi z kapłanami-misjonarzami, niejednokrotnie zwanymi przez nią „,apostołami”, Święta Teresa przekonana była o swoim udziale w misyjnej działalności Kościoła: „Pan Bóg nas połączył, byśmy mogli wykonywać tę samą pracę apostolską i misyjną - ona przez miłość, modlitwę i pokutę, misjonarz przez posługę słowa i trudy misyjne" (Zieliński 238; por. Wilkowski). Pod duchową pieczą Świętej Teresy od Dzieciątka Jezus pozostawali misjonarze: Maurycy Bellière i Adolf Roulland (Wilkowski). Myśl „kochać Jezusa i sprawić, by był kochany” (Zieliński 239) stanowiła poniekąd motto apostolskiej działalności tej świętej, a także jej pism i relacji z misjonarzami. Święta Teresa z Lisieux zamierzała również kontynuować swoją misyjną ,posługę” w wieczności (Gogola; Wilkowski).

Kolejnym rysem misyjnego powołania ad gentes Świętej Teresy była nieustanna gotowość udania się na tereny misyjne. Zresztą już od początku swojego pobytu w Karmelu święta zdradzała przełożonym pragnienie głoszenia 
słowa Bożego na misjach, jednak stan zdrowia nie pozwolił jej zrealizować tego planu. W misyjne powołanie Świętej Teresy wpisało się ponadto pragnienie męczeństwa. Zdaniem Stanisława Zielińskiego, ,idea męczeństwa, przelania krwi dla Chrystusa, to również jeden z elementów misyjnych duchowości Teresy. Pragnienie męczeństwa jest bardzo żywe i obecne [zresztą - Z.K.] w całym życiu Teresy" (Zieliński 242). Towarzyszyły jej pisma misjonarzymęczenników, m.in. biografia i listy Teofana Vénarda, inspirującego ją i pociągającego swoim przykładem. Już jednak jako piętnastolatka natknęła się na „Roczniki Sióstr Misjonarek” (Wilkowski). Za pośrednictwem duchowej więzi z misjonarzami Święta Teresa chciała mieć udział w ich ewentualnym męczeństwie, widząc w oddaniu życia za Jezusa Chrystusa najwyższy wyraz miłości do Zbawiciela. Abstrahując od samego męczeństwa za wiarę, w następujący sposób pisała o swoim misyjnym powołaniu:

Odczuwam powołanie Apostoła. Chciałabym przebiegać ziemię, głosić Twe imię i umieszczać w ziemi niewiernych Twój chwalebny krzyż; chciałabym w tym czasie głosić Ewangelię w pięciu częściach świata aż po najbardziej odległe wyspy. Chciałabym być misjonarzem nie tylko przez przeciąg kilku lat, lecz od stworzenia świata aż do dokonania się wieków (Teresa od Dzieciątka Jezus 1971, 253).

\section{Aktualność misyjnych inspiracji Świętej Teresy}

Dzisiaj także można mówić o aktualności misyjnego przesłania Świętej Teresy od Dzieciątka Jezus. Misyjna droga tej świętej dostępna jest każdemu chrześcijaninowi, a karmelitanka z Lisieux jest jej inspiratorką. Rozbudzone przez Świętą Teresę inspiracje można sprowadzić zasadniczo do trzech, mianowicie do realizacji misji apostolskiej w każdej sytuacji egzystencjalnej, towarzyszenia dziełom misyjnym poprzez modlitwę i ofiarę oraz do stanowiącej istotę życia ofiarnej miłości.

Misję apostolską definiuje się jako spełnienie Chrystusowego polecenia, czyli głoszenie Dobrej Nowiny wszystkim narodom. Jarosław Różański twierdzi, że pod samym pojęciem „misja” kryje się „,posłannictwo Kościoła”, obejmujące trzy sytuacje: misje, duszpasterstwo i nową ewangelizację (Różański 2010, 174). Na mocy chrztu świętego jawi się ono zresztą jako zadanie nałożone na każdego chrześcijanina (por. Piasecki 2013, 57; por. Kluj 2001, 60-61). Wojciech Kluj pisze, że „każdy chrześcijanin ma swoje zadanie, aby współpracować w dziele misyjnym” (Kluj 2001, 64). Sobór Watykański II stwierdza:

Uczniowie Chrystusa, w życiu i działaniu ściśle połączeni z innymi ludźmi, mają nadzieję ofiarować siebie jako prawdziwe świadectwo o Chrystusie i działać na 
rzecz ich zbawienia, także tam, gdzie nie mogą jawnie głosić Chrystusa. Nie szukają bowiem czysto materialnego postępu i dobrobytu, lecz wspierają ich godność i braterską jedność, nauczając prawd religijnych i moralnych, które Chrystus oświecił swoim światłem, i w ten sposób stopniowo otwierają pełniejszy dostęp do Boga. W ten sposób ludzie otrzymują pomoc w osiąganiu zbawienia przez miłość do Boga i bliźniego i zaczyna się ujawniać misterium Chrystusa, w którym pojawił się nowy człowiek stworzony na obraz Boga i w którym objawia się miłość Boża (DM 12).

Jan Paweł II w encyklice Redemptoris missio dopowiada, że wspomniane zadanie ,rodzi się z wiary w Jezusa Chrystusa, co każdy wierny proklamuje w wyznaniu wiary trynitarnej” (RM 4). Niekoniecznie też misja apostolska musi być realizowana np. w odległych regionach świata.

Jan Paweł II zwraca uwagę na istnienie we współczesnym świecie trzech sytuacji misyjnych. Taką sytuacją jest:

przede wszystkim ta, ku której kieruje się działalność misyjna Kościoła: narody, grupy ludzi, środowiska społeczno-kulturowe, w których Chrystus i Jego Ewangelia nie są znane, albo w których brak wspólnot wystarczająco dojrzałych, by mogły wcielać wiarę we własne środowisko [...]. To jest w ścisłym sensie misja ad gentes. Istnieją dalej wspólnoty chrześcijańskie, które posiadają odpowiednie i solidne struktury kościelne, mają żarliwość wiary i życia, promieniują świadectwem dawanym Ewangelii w swym środowisku i czują się zobowiązane do misji powszechnej. W nich prowadzona jest działalność duszpasterska. Istnieje wreszcie sytuacja pośrednia, zwłaszcza w krajach o chrześcijaństwie dawnej daty, ale czasem również w Kościołach młodych, gdzie całe grupy ochrzczonych utraciły żywy sens wiary albo wprost nie uważają się już za członków Kościoła, prowadząc życie dalekie od Chrystusa i od Jego Ewangelii. W tym wypadku zachodzi potrzeba 'nowej ewangelizacji' albo 're-ewangelizacji' (RM 33).

Wzorując się na Świętej Teresie, można podejmować odpowiedzialność za misje, a tym samym poniekąd w nich uczestniczyć, dlatego, żeby być misjonarzem, niekonieczny jest wyjazd na tereny misyjne, gdyż de facto „wszyscy chrześcijanie, członkowie Kościoła, na mocy chrztu świętego są współodpowiedzialni za działalność misyjną" (RM 77). Można zatem być misjonarzem w każdej czasoprzestrzeni, dzięki też temu, że misje ad gentes nie ograniczają się tylko do geografii, ale dotyczą chociażby zjawisk społecznych i obszarów kulturowych, czyli współczesnych ,areopagów”. Także w tym miejscu warto oddać głos Janowi Pawłowi II, który w Redemptoris missio stwierdza:

Jest wiele innych 'areopagów' współczesnego świata, ku którym winna się kierować działalność misyjna Kościoła. Na przykład zaangażowanie na rzecz poko- 
ju, rozwoju i wyzwolenia ludów, praw człowieka i narodów, przede wszystkim mniejszości, działanie na rzecz kobiety i dziecka, ochrona świata stworzonego, to wszystko dziedziny ludzkiej działalności, które należy rozjaśnić światłem Ewangelii (RM 37).

Te i inne współczesne ,areopagi” jawią się jako idealne miejsca do realizacji misyjnego powołania przez chrześcijan w ich lokalnych społecznościach. Realizacja ta dokonuje się rozmaitymi drogami. Święta Teresa uskuteczniała swoje apostolskie powołanie zwłaszcza za pośrednictwem modlitwy i ofiary. W Dziejach duszy napisała: „Nie ulega wątpliwości, że przede wszystkim modlitwą i ofiarą przynosi się pomoc misjonarzom [...]" (Teresa od Dzieciątka Jezus 2002, 298), opisując również swoje drobne ofiary ponoszone dla Jezusa Chrystusa w celu zbawienia dusz, chociażby następującą:

Innym razem znalazłam się w pralni naprzeciw siostry, która, ilekroć podnosiła chustki na swojej ławce, opryskiwała mi twarz brudną wodą. Początkowo miałam odruch, by się cofnąć i otrzeć twarz, a tym samym zwrócić uwagę siostrze, która mnie kropiła, najspokojniej w świecie oddając mi tę przysługę. Zaraz jednak przyszło mi na myśl, że postąpiłabym bardzo niemądrze, gdybym odrzuciła te skarby, tak wspaniałomyślnie mi ofiarowane, i bardzo uważałam, by nie dać poznać po sobie wewnętrznych zmagań. Usiłowałam obudzić w sobie pragnienie, by mnie jak najobficiej oblewano brudną wodą, i doszłam do tego, że w końcu rzeczywiście polubiłam ten nowy rodzaj pokropienia i przyrzekłam sobie, że na drugi raz wrócę na to uprzywilejowane miejsce, gdzie można otrzymać tyle skarbów. Widzisz więc, Matko ukochana, że jestem maleńką duszą, która może ofiarować dobremu Bogu tylko maleńkie rzeczy [...] (Teresa od Dzieciątka Jezus 2002, 296; por. Franciszek 40-45; 119-121).

Analogiczne środki urzeczywistniania powołania misyjnego przybliża także Jan Paweł II w encyklice Redemptoris missio. Twierdzi on mianowicie, że:

wśród form uczestnictwa pierwsze miejsce zajmuje współpraca duchowa: modlitwa, ofiara, świadectwo życia chrześcijańskiego. Modlitwa winna towarzyszyć misjonarzom na ich drodze, aby głoszenie Słowa odniosło skutek dzięki łasce Bożej (RM 78).

Wymienienie modlitwy jako priorytetowej nie zaskakuje, jeśli uwzględni się choćby to, że już Święty Paweł prosił lokalne wspólnoty eklezjalne o modlitwę, aby mógł śmiało głosić Jezusa Chrystusa poganom. Modlitwa w intencji misji i misjonarzy łączy się z ofiarą. Także poprzez ofiarę chrześcijanin, zwłaszcza chory i cierpiący (analogicznie do Świętej Teresy od Dzieciątka Jezus), może aktywnie partycypować w ewangelizacyjnej misji. Dlatego Jan 
Paweł II następująco zwraca się do duszpasterzy duchowo opiekujących się chorymi:

Misjonarzowi w jego ofierze winni towarzyszyć wierni i podtrzymywać go własną ofiarą. Dlatego też proszę tych wszystkich, którzy pełnią posługę duszpasterską wśród chorych, by pouczali ich o zbawczej wartości cierpienia i zachęcali do ofiarowania go Bogu za misjonarzy. Przez taką ofiarę chorzy stają się również misjonarzami, jak podkreślają pewne stowarzyszenia powstałe wśród nich i dla nich (RM 78).

Nie można pominąć też miłości będącej dla Świętej Teresy skuteczną, również misyjnie, „osią działania”. Jan Paweł II wyjaśnia, że to właśnie „,miłość jest zasadą działania oraz celem, do którego należy dążyć” (RM 60), dopowiadając:

Misjonarz jest człowiekiem miłości: aby mógł głosić każdemu bratu, że jest kochany przez Boga i on sam może kochać, misjonarz musi dawać świadectwo miłości względem wszystkich, poświęcać życie dla bliźniego. Misjonarz jest bratem wszystkich, ma w sobie ducha Kościoła, jego otwartość i zainteresowanie dla wszystkich narodów i ludzi, zwłaszcza dla najmniejszych i najuboższych (RM 89).

Przykłady misyjnych inspiracji, zaczerpniętych z życia Świętej Teresy od Dzieciątka Jezus, można jeszcze mnożyć. Także aktualności jej misyjnego przesłania trudno zaprzeczyć. Mimo iż współczesność dostarcza nowych horyzontów i form misyjnej działalności Kościoła, to nadal stanowiące wyraz misyjnego zaangażowania chrześcijan - miłość, modlitwa i ofiara - pozostają niezmienne. Nie odnoszą się one jednak tylko do apostolskiej misji, ponieważ, jak twierdzi Szczepan Praśkiewicz, „stosownym jest, aby budując Królestwo Boże $\mathrm{w}$ ramach codzienności, i dzisiaj położyć nacisk na potrzebę miłości, modlitwy i ofiary, niezależnie od swego powołania" (Praśkiewicz). Konieczność tego misyjnego zaangażowania zakorzeniona jest w chrzcie świętym (Sakowicz 2005, 170; por. Sakowicz 2005, 180).

Misyjne zaangażowanie każdego zresztą chrześcijanina, znajdujące uzasadnienie w sakramencie chrztu świętego, nie musi obierać sobie za cel dalekich lądów, gdyż nie zawsze w takim ujęciu byłoby i będzie możliwe. Nie zawsze także wiąże się z bezpośrednim udziałem w „ewangelizacji”, mającej miejsce na „krańcach świata”. Świadczy o tym najwyraźniej postawa świętej z francuskiego Lisieux, karmelitanki Teresy od Dzieciątka Jezus. Niekoniecznie też udział w misyjnej działalności łączyć się będzie i łączy z pracami wśród tych, którzy poznają lub dopiero co poznali Jezusa Chrystusa i Jego Ewangelię. W ślad za Świętą Teresą z Lisieux równie owocne może być zaan- 
gażowanie w misje poprzez modlitwę, post, cierpienie, pokutę czy duchowe wsparcie za pośrednictwem chociażby korespondencji z misjonarzami i misjonarkami. Jako wzór takiej postawy, czyli de facto gorliwego i pełnego misyjnego zaangażowania, jawi się właśnie tutaj wspomniana święta, dlatego też uczyniono ją, zdaje się, że słusznie, patronką misji. Jednakże otrzymała ona ów tytuł od papieża Piusa XI również ze względu na szczególne wstawiennictwo za misjonarzami, także pośmiertne. Za przykład skuteczności Świętej Teresy niech posłuży sytuacja z misji oblackich. Kiedy prowadzone od kilku lat w północnej Kanadzie misje okazały się bezowocne, a biskup napisał do jednego z misjonarzy, że jeśli w kolejnym roku nie ochrzci żadnego z tubylców, to odwoła go z misji, oblat ten, oprócz listu od hierarchy, otrzymał tego samego dnia broszurkę o Świętej Teresie od Dzieciątka Jezusa i dołączoną do niej szczyptę ziemi z jej grobu. W owej broszurce przeczytał, że Święta Teresa zapewniała o „deszczu róż”, czyli łask dla tych, którzy będą prosić ją o wstawiennictwo. Misjonarze modlili się za przyczyną Świętej Teresy, a nawet posypali głowy ludzi wspomnianą szczyptą ziemi. Okazało się potem, że wielu $\mathrm{z}$ autochtonów zaczęło prosić o chrzest. Właśnie na tej podstawie biskup Owidiusz Charlebois, w porozumieniu z innymi biskupami Kanady, skierował do Piusa XI prośbę, by ogłosił Świętą Teresę „,powszechną patronką misji”, co też papież uczynił 17 maja 1925 r. w czasie kanonizacji, podczas której misjonarz, o. Rolland, był świadkiem (Zielenda).

\section{THE MISSIONARY DIMENSION OF THE SPIRITUALITY OF ST. TERESA OF THE CHILD JESUS}

\section{Summary}

Currently, 92 years have passed since the announcement of St. Teresa of the Child Jesus, patron of the mission. There are still questions about the legitimacy of this act made by Pope Pius XI. However, this article focuses primarily on the timeliness of this patronage, and not on the act itself and its legitimacy. First, it presents the missionary life of the Saint of Lisieux, which is a de facto missionary feature of her spirituality, and then the "missionary thought" of Saint. Teresa of the Infant Jesus is juxtaposed with the teaching of the Church, represented by Vatican II and Redemptoris Missio John Paul II.

Keywords: missions; Teresa of the Child Jesus; patron saint of missionaries; spirituality

Słowa kluczowe: misje; Teresa od Dzieciątka Jezus; patronka misji; duchowość 


\section{WYKAZ SKRÓTÓW}

DM - Sobór Watykański II, Dekret o działalności misyjnej Kościoła „Ad gentes divinitus”

RM - Jan Paweł II, Encyklika „Redemptoris missio”

\section{BIBLIOGRAFIA}

Bernyś, Mariusz. „Boże miłosierdzie w doświadczeniu św. Teresy od Dzieciątka Jezus i św. Faustyny Kowalskiej. Studium porównawcze.” Warszawskie Studia Teologiczne XX 1 (2007): 179-195 .

„Dekret o misyjnej działalności Kościoła Ad gentes divinitus”. Sobór Watykański II. Konstytucje Dekrety Deklaracje. Poznań: Pallottinum, 2002.

Franciszek. Evangelii Gaudium. Kraków: Wydawnictwo M, 2013.

Gogola, Jerzy. Dlaczego św. Teresa od Dzieciatka Jezus jest patronka misji? Dostęp 6 stycznia 2019. $<$ http://www.karmel.pl/dlaczego-sw-teresa-od-dzieciatka-jezus-jest-patronka-misji/>

Jan Paweł II. Divini amoris scientia. Kraków: Wydawnictwo Karmelitów Bosych, 2002.

Jan Paweł II. Redemptoris missio. Wrocław: Wydawnictwo Tum, 1995.

Kluj, Wojciech. „Pneumatologiczne perspektywy teologii misji w Redemptoris missio.” Collectanea Theologica 71.2 (2001): 59-76.

Piasecki, Piotr. „Trynitarne podstawy duchowości misyjnej.” Duchowość misyjna w posoborowej nauce Kościoła katolickiego. Poznań: Redakcja Wydawnictw Wydziału Teologicznego UAM, 2013. 41-62.

Praśkiewicz, Szczepan. Misyjny patronat św. Teresy od Dzieciątka Jezus. Dostęp 6 stycznia 2019. $<\mathrm{http} / / /$ www.karmel.pl/patronat-misyjny/>

Różański, Jarosław: „Głoszenie Ewangelii i promocja ludzka - dwa równorzędne filary działalności misyjnej." Studia Ecologiae et Bioethicae 8.2 (2010): 173-186.

Sakowicz, Eugeniusz. „Powszechna odpowiedzialność za misje ad gentes według encykliki Redemptoris missio Jana Pawła II." Collectanea Theologica. Biuletyn Misjologiczno-Religioznawczy (95), 75.4 (2005): 167-182.

Teresa od Dzieciątka Jezus. Dzieje duszy. Kraków: Wydawnictwo Karmelitów Bosych, 2002.

Teresa od Dzieciątka Jezus. Dzieje duszy. Londyn: Katolicki Ośrodek Wydawniczy Veritas, 1957.

Teresa od Dzieciątka Jezus. Pisma. Kraków: Wydawnictwo Karmelitów Bosych, 1971.

Wilkowski, Rafał. Droga św. Teresy od Dzieciątka Jezus do ogłoszenia Patronka misji i niegasnaca aktualność jej misyjnego patronatu. [Materiaty z Sesji upamiętniajacej 75-lecie patronatu misyjnego św. Teresy od Dzieciatka Jezus w Wyżsym Seminarium Duchownym Misjonarzy Oblatów w Obrze (13 grudnia 2002)]. Kraków: Wydawnictwo Karmelitów Bosych, 2003. Dostęp 14 stycznia 2019. <http://absta.pl/droga-w-teresy-od-dziecitka-jezus-do-ogoszenia-patronk-misji. $h \mathrm{tml} \geq$

Zielenda, Krzysztof. Pourqoi sainte Thérese a-t-elle été proclamé patronne des missions? Dostęp 7 lipca 2019. <http://www.centremazenod.org/nouvelles/pourquoi-sainte-therese-a-t-elle-eteproclamee-patronne-des-missions $>$

Zieliński, Stanisław. Święta Teresa z Lisieux słowem Boga dla świata. [I Karmelitański Tydzień Duchowości - 9-12 marca 1998]. Red. Jerzy Wiesław Gogola. Kraków: Karmelitański Instytut Duchowości i Wydawnictwo Karmelitów Bosych, 1998. 234-243.

Zofia KaCzMareK, doktorantka na Wydziale Teologicznym UAM w Poznaniu. 
